\title{
A transition from the BPharm to the PharmD degree in five selected countries
}

\author{
Teeraporn SUPAPAAN ${ }^{(D)}$, Bee Y. LOW ${ }^{(D)}$, Payom WONGPOOWARAK $(D)$, Summana MOOLASARN, \\ Claire ANDERSON ID. \\ Received (first version): 4-Jul-2019 \\ Accepted: 18-Aug-2019 \\ Published online: 21-Aug-2019
}

\begin{abstract}
This review focuses on the studies and opinions around issues of transition from the BPharm to the PharmD degree in the U.S., Japan, South Korea, Pakistan and Thailand.

The transition to the clinically orientated PharmD degree in many countries was seen to be a means of developing the profession. However, some countries have both clinically-oriented and pharmaceutical sciences-oriented PharmD programme that are designed to meet the needs of their countries. Each country created a different process to handle the transition to an all-PharmD programme, but mostly had the process of school accreditation mandated by the regulatory bodies. The main barrier to the transition in most of the countries was the issue of educational quality. A set of indicators is needed to measure and monitor the impact/outcome of the PharmD degree.

Each country has different needs due to the different contexts of health care systems and the scope of pharmacy practice. In order to increase their chances of benefiting from the new programme, academic leaders should critically assess their countries' needs before deciding to adopt a PharmD programme.
\end{abstract}

Keywords

Education, Pharmacy; Schools, Pharmacy; Students, Pharmacy; Pharmaceutical Services; Clinical Competence; Curriculum; Program Development; United States; Japan; Republic of Korea; Pakistan; Thailand

\section{INTRODUCTION}

The Doctor of Pharmacy (PharmD) is a professional doctorate degree, also known as a clinical doctorate - a term only used in the health professions. ${ }^{1}$ The professional doctorate degree emphasises practice competencies, which is different from an academic doctorate, such as Doctor of Philosophy (PhD) that focuses on knowledge or original research production. ${ }^{1}$ The United States was the first country that has moved to a 6-year PharmD degree as the sole credential for the professional pharmacy programme and focuses mainly on clinical pharmacy. ${ }^{2}$ There is an increasing global trend for example in countries towards PharmD degree education. ${ }^{3-9}$ The list of countries that transitioned from the BPharm to the PharmD degree, as their entry-level qualification are as follows, U.S., Canada (plan to offer an all-PharmD in 2020), Hungary, Italy, Japan, South Korea, Pakistan, Saudi Arabia, Thailand, Benin, Cameroon, Republic of Congo, Senegal, Tunisia, Nigeria and Gana. ${ }^{5-9}$ This paper aims to review the key publications demonstrating the opinions around issues of transition from the BPharm to the PharmD degree in the five selected countries, which are the U.S., Japan, South Korea, Pakistan and Thailand.

Teeraporn SUPAPAAN. PhD. Faculty of Pharmaceutical Sciences, Ubon Ratchathani University. Ubon Ratchathani (Thailand). teeraporn.s@ubu.ac.th

Bee Yean LOW. PhD. School of Pharmacy, Faculty of Science and Engineering, University of Nottingham Malaysia. Selangor, (Malaysia). BeeYean.Low@nottingham.edu.my

Payom WONGPOOWARAK. PhD. Department of Clinical

Pharmacy, Faculty of Pharmaceutical Sciences, Prince of Songkla

University. Songkhla (Thailand). wpayom@gmail.com

Summana MOOLASARN. PhD. Faculty of Pharmaceutical

Sciences, Ubon Ratchathani University. Ubon Ratchathani

(Thailand).summana@hotmail.com

Claire ANDERSON. PhD. School of Pharmacy, University of

Nottingham. Nottingham (United Kingdom).

Claire.Anderson@nottingham.ac.uk
The countries were chosen because there were a number of publications about the transition available. The basic information regarding the pharmacy workforce and education in those selected countries is presented in Table 1. The most popular area of practice in the developed countries is community pharmacy, due to the structure of their health care systems that need a high number of pharmacists in such pharmacies. On the other hand, the popular area of practice in Pakistan is the pharmaceutical industry because of the successful pharmaceutical industry in Pakistan. ${ }^{10}$ Thailand has hospital pharmacy as the most popular area of practice, due to the public hospitals being the country's main healthcare facilities. ${ }^{11}$

\section{Educational pathways to become a pharmacist in the five} selected countries

The pharmacy educational systems are similar in course length most are approximately 6 years if pre-entry standards and internships are included (Table 2). ${ }^{3,4,12-16}$ All countries have a similar education system to cater for those who wish to become a pharmacist: the students enter from secondary school except for the U.S. and South Korea where school leaving qualifications are lower and entry is after a minimum 2 years at the university, followed by a 4 year pharmacy course with one year training experience and then a licensure examination. ${ }^{13-15}$ All countries require registration assessment of new pharmacists or their national licensure examination.

\section{Scope of pharmacy practice in the five selected countries}

Pharmacists in all countries provide clinical pharmacy services but at different levels of implementation; for example, pharmacists in developed countries have many supporting systems for the implementation of pharmaceutical care practice. On the other hand, in 


\begin{tabular}{|c|c|c|c|c|c|}
\hline Characteristics & U.S. $^{45,71,72}$ & Japan $^{51-53,55,73}$ & South Korea ${ }^{20,74}$ & Pakistan ${ }^{6,10,75-77}$ & Thailand $^{77,78}$ \\
\hline \multicolumn{6}{|l|}{ General aspects } \\
\hline Population (millions) & 273 & 128 & 49.8 & 176 & 67 \\
\hline GDP per capita (USD) (2013) & 54,353 & 42,983 & 18,373 & 4,700 & 14,400 \\
\hline $\begin{array}{l}\text { Number of licensed pharmacists (per } \\
10,000 \text { of population) }\end{array}$ & 249,642 (9) & $276,517(21)$ & $53,492(6.5)$ & $12,000(0.7)$ & $28,272(4.2)$ \\
\hline Pharmacy workforce by practice ${ }^{79,80}$ & $\begin{array}{c}C^{a} 65 \%, H^{b} 25 \%, \\
O^{c} 10 \%\end{array}$ & $\begin{array}{l}\text { C } 49.6 \%, \text { H } 19.4 \% \text {, } \\
I^{d} 11.9 \%, \text { O } 19.1 \%\end{array}$ & $\begin{array}{c}\text { C } 28.6 \%, \text { I } 21 \%, \\
\text { H } 18.3 \%, \text { O } 32.1 \%\end{array}$ & $\begin{array}{l}\text { I 55\%, C } 10 \% \\
\text { H } 10 \%, \text {, } 25 \%\end{array}$ & $\begin{array}{l}\text { H } 40 \%, \text { C } 17 \% \text {, } \\
\text { I } 10 \%, \text { O } 33 \%\end{array}$ \\
\hline Community pharmacies ${ }^{79}$ & 37,539 & 71,970 & 20,633 & 80,000 & 11,592 \\
\hline Re-licensure required & $\begin{array}{l}\text { Requirements vary by } \\
\text { state }\end{array}$ & $\begin{array}{c}\text { No renewal system in } \\
\text { pharmacy license }\end{array}$ & $\mathrm{N} / \mathrm{A}$ & $\mathrm{N} / \mathrm{A}$ & Renewed every 5 years \\
\hline \multicolumn{6}{|l|}{ Pharmacy education } \\
\hline No. of pharmacy institutions ${ }^{6}$ & 129 & 74 & 35 & 43 & 19 \\
\hline No. of pharmacy technicians institution ${ }^{79}$ & 700 & 0 & 0 & 9 & 17 \\
\hline Pharmacy graduate per year ${ }^{6}$ & 12,719 & 9,912 & 1,372 & 4,000 & 1,680 \\
\hline $\begin{array}{l}\text { Year that transition to an all-PharmD } \\
\text { programme has been started }\end{array}$ & 2000 & 2006 & 2009 & 2004 & 2010 \\
\hline Academic programme, length (years) & PharmD $^{\mathrm{e}}, 6^{\dagger}, 4^{\mathrm{g}}$ & Bachelor, 6 & Bachelor, 6 & PharmD, 5 & PharmD, 6 \\
\hline Practice training $^{6}$ & $\begin{array}{l}\mathrm{C}, \mathrm{H}, \mathrm{O}(1,000-1,800 \\
\text { practice hours) }\end{array}$ & C, H (6 months) & $\mathrm{N} / \mathrm{A}$ & $\mathrm{C}, \mathrm{H}$ & $\begin{array}{l}\mathrm{C}, \mathrm{H}, \mathrm{I}, \mathrm{O}(2,000 \text { practice } \\
\text { hours })\end{array}$ \\
\hline National licensing exam & Required & Required & Required & Required & Required \\
\hline $\begin{array}{l}\text { The programme that bridge the } \\
\text { academic gap between 4-, 5- and 6- } \\
\text { year pharmacy programme }\end{array}$ & $\begin{array}{c}\text { Non-traditional } \\
\text { PharmD programme }\end{array}$ & $\begin{array}{l}\text { The new curriculum- } \\
\text { support training }\end{array}$ & $\begin{array}{l}\text { Master degree } \\
\text { programme in } \\
\text { clinical pharmacy }\end{array}$ & $\mathrm{N} / \mathrm{A}$ & $\begin{array}{c}\text { Master degree } \\
\text { programme in clinical } \\
\text { pharmacy, } \\
\text { Residency training } \\
\text { programme }\end{array}$ \\
\hline
\end{tabular}

${ }^{a} \mathrm{C}=$ Community pharmacy; ${ }^{b} \mathrm{H}=$ Hospital pharmacy; ${ }^{\mathrm{C}} \mathrm{O}=$ Others; ${ }^{\mathrm{d}} \mathrm{I}=$ Industrial pharmacy; ${ }^{\mathrm{e}}$ nearly half of students hold a bachelor or higher degrees; ${ }^{f}$ for PharmD programme with no pre-pharmacy requirements for admission; ${ }^{\mathrm{g}}$ for PharmD programme that requires at least 2-years of specific pre-professional (undergraduate) coursework prior to 4-academic year of professional study.

developing countries pharmaceutical care implementation still encounters a number of challenges, including the absence of a recognized reimbursement system. ${ }^{17,18}$ Pharmacists in the U.S. can be given the authority to be supplementary or independent prescribers via collaborative practice agreements that depend on state regulations; while pharmacists in Japan, South Korea, Pakistan, and Thailand have prescribing authority for 'pharmacist only medicines (POM)' and the over-the counter (OTC) medicines for the symptomatic treatment of minor conditions.

\section{THE TRANSITION FROM THE BPHARM TO THE PHARMD DEGREE}

The key publications demonstrating the opinions evolving around the issues of transition from the BPharm to the PharmD degree have been reviewed. There are four main issues that consistently emerged as follows;

1. Needs and context: It seems that the intention of the transition to the PharmD degree in many countries was to use pharmacy education as a way to guide the future of the profession, especially shifting to a more clinically oriented degree. ${ }^{4,19}$ On the other hand, Pakistan, South Korea and Thailand needed to expand their pharmacists' roles in clinical pharmacy, as well as meeting the high demand for pharmacists in the pharmaceutical industry. ${ }^{16,20-24}$

It was suggested that the bachelor degree was still needed and should be continued as a basic degree programme, in order to develop pharmacists who have knowledge and skills to work in non-direct patient care areas like the pharmaceutical industry and marketing. ${ }^{21,22,24}$
2. Process: The process of the transition from the BPharm to the PharmD has created similar situations among several countries as follows:

1) Debating about the transition: There were debates about the transition from the BPharm to the PharmD degree for a long period of time in order to establish a consensus at the national level. ${ }^{19}$

2) Mandating by the regulatory bodies: Each country had their regulatory bodies who mandated the PharmD programme as the entry-level pharmacy programme, by moving toward some sort of standardised credentialing methods. ${ }^{2,19}$ For example, the curriculum must have been revised to fit the new PharmD programme in order to receive its accreditation or to produce pharmacy graduates who are eligible to sit for the licensure examination. ${ }^{2,26,27}$

3) Supportive regulations concerning the provision of pharmaceutical care in practice settings: In some countries, there are factors that support pharmacists to take up their new roles in direct patient care activities. For example, in the U.S., the pharmaceutical care service called medication therapy management (MTM), has been codified into law, and Medicare Part D providers are required to offered MTM services to a specific subset of patients. ${ }^{19,25,28-30}$ This situation differs from many developing countries, which have changed to the PharmD degree, that still have no supporting regulations and often no professional fee framework to reward pharmacists for making high-risk clinical decisions. ${ }^{4,31,32}$

3. Barriers to the transition: The transition from bachelor degree to doctoral level, in most of countries raised concerns about education quality. ${ }^{32}$ Most developing 


\begin{tabular}{|c|c|c|c|c|c|c|c|c|c|c|c|c|c|c|c|c|c|}
\hline $\begin{array}{l}\text { Approximate } \\
\text { grade }\end{array}$ & 1 & 2 & 3 & 4 & 5 & 6 & 7 & 8 & 9 & 10 & 11 & 12 & & & & & \\
\hline $\begin{array}{l}\text { US } \\
\text { (6-year PharmD) }\end{array}$ & \multicolumn{6}{|c|}{ Primary school } & \multicolumn{6}{|c|}{ Secondary school } & $\begin{array}{l}\text { 2-year } \\
\text { prerequisites or } \\
\text { obtaining a } \\
\text { transferable } \\
\text { bachelors' } \\
\text { degree } \\
\text { pharmacy }\end{array}$ & \multicolumn{3}{|c|}{$\begin{array}{l}\text { 4-year School of Pharmacy, } \\
\text { including clerkship 1,000-1,800 } \\
\text { practice hours } \\
\text {-IPPE } 300 \text { hours during first } 3 \\
\text { years of course } \\
\text {-APPE } 36 \text { weeks in the fourth } \\
\text { year }\end{array}$} & $\begin{array}{l}\text { State Board } \\
\text { exam }\end{array}$ \\
\hline $\begin{array}{l}\text { Japan } \\
\text { (6-year BPharm) }\end{array}$ & \multicolumn{6}{|c|}{ Primary school } & \multicolumn{3}{|c|}{$\begin{array}{l}\text { Junior High } \\
\text { school }\end{array}$} & \multicolumn{3}{|c|}{ High school } & \multicolumn{4}{|c|}{$\begin{array}{l}\text { 6-year BPharm, including } 6 \text { months internship } \\
\text { (Prior to start outside practice: } S_{\text {tudents have to }} \\
\text { take common exam at school }\left(\mathrm{CBT}^{\mathrm{c}}+\mathrm{OSCE}^{\mathrm{d}}\right) \text { in the } \\
\text { fourth year) }\end{array}$} & $\begin{array}{l}\text { National } \\
\text { Board exam }\end{array}$ \\
\hline $\begin{array}{l}\text { Korea } \\
\text { (2+4 Pharmacy } \\
\text { programme) }\end{array}$ & \multicolumn{6}{|c|}{ Primary school } & \multicolumn{3}{|c|}{$\begin{array}{l}\text { Junior High } \\
\text { school }\end{array}$} & \multicolumn{3}{|c|}{ High school } & $\begin{array}{l}\text { 2-year } \\
\text { Pre-pharmacy } \\
+ \text { PEET }^{\mathrm{e}}\end{array}$ & \multicolumn{3}{|c|}{$\begin{array}{l}\text { 4-year School of Pharmacy, } \\
\text { including clerkship in the final } \\
\text { year; -IPPE } 2 \text { credits ( } 70 \\
\text { hours);APPE } 1 \text { years ( } 33 \\
\text { weeks/1330 hours for } 28 \\
\text { credits) }\end{array}$} & $\begin{array}{l}\text { National } \\
\text { Board exam }\end{array}$ \\
\hline $\begin{array}{l}\text { Pakistan } \\
\text { (5-year PharmD) }\end{array}$ & \multicolumn{5}{|c|}{ Primary school } & \multicolumn{3}{|c|}{$\begin{array}{l}\text { Secondary } \\
\text { school (lower } \\
\text { level G6-8) }\end{array}$} & \multicolumn{4}{|c|}{$\begin{array}{l}\text { Secondary school } \\
\text { (upper level G9-12) }\end{array}$} & \multicolumn{4}{|c|}{$\begin{array}{l}\text { 5-year PharmD (There is no clarity } \\
\text { regarding pharmacy practice } \\
\text { experience) }\end{array}$} & N/A \\
\hline $\begin{array}{l}\text { Thailand } \\
\text { (6-year PharmD) }\end{array}$ & \multicolumn{7}{|c|}{$\begin{array}{l}\text { Primary school } \\
\text { (6-11 years old: Prathom) }\end{array}$} & \multicolumn{5}{|c|}{$\begin{array}{l}\text { High school } \\
\text { (12-18 years old: Mattayom) }\end{array}$} & \multicolumn{4}{|c|}{$\begin{array}{l}\text { 6-year PharmD, including } 2,000 \text { practice hours } \\
\text {-IPPE }^{\mathrm{a}} 400 \text { hours during the fourth year } \\
\text {-APPE }^{\mathrm{b}} 1,600 \text { hours during the fifth and the sixth } \\
\text { year }\end{array}$} & $\begin{array}{l}\text { National } \\
\text { Licensure } \\
\text { exam }\end{array}$ \\
\hline
\end{tabular}

countries may lack such crucial factors as experienced clinical academic staff, competent preceptors, collaboration with hospitals. Other challenges are likely to include insufficient infrastructure, and economic resources to provide adequate internships, all of which might affect the quality of pharmacists' education. ${ }^{4,33}$

4. Impact/outcome: There is still insufficient information to develop a definite argument to support a relationship between success indicators and the introduction to the PharmD degree. ${ }^{4,34}$ Anderson and Futter suggested that there should be a set of indicators to measure and monitor the impact of the PharmD degree. ${ }^{4}$ In the following section, the transition from the BPharm to the PharmD programme or similar programme in the U.S., Japan, South Korea, Pakistan and Thailand has been reviewed.

\section{THE UNITED STATES OF AMERICA}

\section{Need for the change}

The U.S. pharmacy profession decided to move to an allPharmD programme over 20 years ago, in an effort to enhance pharmacists' competencies and reflect growth in the knowledge base of the profession. ${ }^{1,35}$ There was a need to incorporate new competencies into the pharmacy curriculum and a need to provide robust pharmaceutical care, together with the potential for improved economic outcomes. $^{19}$

\section{Process of the transition to the PharmD degree}

The origin of the debate over whether to offer the entry level PharmD as the sole professional degree began back in 1948, when the American Council on Education (ACE) recommended that the professional pharmacy curriculum should be a 6 -year programme. In 1989, $56 \%$ of U.S. pharmacy schools still only offered the bachelor degree, $14 \%$ offered the PharmD degree and $30 \%$ offered both degrees.

The American Association of Colleges of Pharmacy (AACP) President William Miller appointed a task force, which was termed The AACP Commission of Implement Change in Pharmaceutical Education, to develop recommendations to guide pharmacy education to meet the demands of the profession, the health care system and the society. ${ }^{25,36,37}$

In 1989, the Accreditation Council for Pharmacy Education (ACPE), the body that sets educational standards and accredits colleges of pharmacy, stated that its intent was to accredit only PharmD degree programmes as the entrylevel degree into the pharmacy profession; suggesting the year 2000 as a probable target date. ${ }^{25}$ This declaration drove much discourse among educators who were doubtful of obtaining adequate resources to add another year into the curricula. Concern was also expressed over the practitioners: in particular fearful that bachelor practitioners would be disenfranchised if pharmacy schools produced only PharmD graduates. ${ }^{25}$ Debates about the PharmD as the entry-level degree have continued for approximately 40 years but the issue was finally resolved in July 1992, at the annual meeting of the AACP. ${ }^{25}$ The delegates voted overwhelmingly to endorse the PharmD degree as the sole degree leading into the practice of pharmacy. ${ }^{25}$ In 1997 with the publication of Standards 2000, the ACPE put in place the requirement that all pharmacy schools develop a plan for transitioning from two degrees to one degree by July $1,2000 .^{19}$ Then, all schools 
and colleges of pharmacy revised their curricula in order to receive accreditation.

Enablers

1) Leadership: The close association between the AACP and ACPE played a vital role in the strength of the AACP's suggestions. The AACP influenced the ACPE to revise accreditation standards for all school of pharmacy to include the PharmD degree and the educational elements necessary for providing pharmaceutical care. ${ }^{38,39}$

2) Evidence of support: Between 1986-1991, many articles focused on the important of preparing pharmacists for the changing of the pharmacy profession by shifting towards a more comprehensive patient-focused care and other factors that stimulated a need for change in pharmacy education, particularly the rising cost of health care. ${ }^{19,35,39}$ 41 There were also a number of studies regarding measuring the effect of the PharmD graduates in practice, compared to the Bachelor of Science in Pharmacy programmes. The conclusions that might be drawn from these studies were as follows: job activities and professional satisfaction of BPharm and the entry-level PharmD graduates were not significantly different. ${ }^{34,42}$ However, most of the studies were limited in their methodology due to such issues as low response rates and imbalanced representation by degrees. ${ }^{7,34}$

Barriers

The barriers that have been mentioned are as the follows: 1) lengthening the education programme for a year would cost money. Tuition fees would increase, student debt would rise, and the state would have to contribute more funding to support the programme. ${ }^{27}$ 2) there would be a lack of competent preceptors. ${ }^{43}$

\section{The U.S. PharmD curriculum}

Compared to the BPharm, the PharmD curriculum was extended by one year that included additional pharmacotherapy and patient care coursework, plus expanded experiential learning with specified activities emphasising clinical skills; for example, counselling patients or advising other health professionals on drug use issues. ${ }^{44,47-49}$ Even though the transition from the BPharm to the PharmD programme in the U.S. has been accomplished, the American College of Clinical Pharmacy (ACCP) and the American Society of Health-System Pharmacists (ASHP) think that the pharmacy education should be better. Both organisations share a common vision that all pharmacists who are involved with direct patient care will be required to complete a residency prior to entering practice by $2020 .^{50}$

\section{JAPAN}

\section{Need for the change}

The curriculum change was made to address the strong demand for highly competent pharmacists to deliver pharmaceutical care for the health care teams. ${ }^{51}$

\section{Process of the transition to the PharmD degree}

Changing to a 6-year pharmacy degree programme was proposed by the Japan Pharmaceutical Association (JPA) in
1973. However, the change was not implemented until 2003, when the Council for Pharmaceutical Education approved the transition. ${ }^{52}$ In 2006, the pharmacy education system in Japan was in transition from the traditional 4year programme into two programmes, namely: a traditional 4-year programme and a new 6-year Bachelor of Pharmacy programme, which is similar to the PharmD programme. ${ }^{51,52}$ The traditional 4-year programme emphasised pharmaceutical sciences due to the career decisions of graduates; approximately $80 \%$ of Japanese pharmacy graduates enter the pharmaceutical industry. ${ }^{31}$ The 4-year BPharm graduates are not able to obtain a national pharmacy license. ${ }^{53}$ The 6 -year programme is mandatory for registration for the licensure examination and is related to the accreditation system. ${ }^{54}$ Thus, only the graduates from the new 6-year programme are able to obtain a national pharmacy license. ${ }^{51}$

Enablers

There is a prescription law that separates prescribing and dispensing in Japan (Bungyo). ${ }^{28,55}$ This law allows opportunities for pharmacists to provide pharmaceutical care activities within the scope of the prescription law. ${ }^{31,57}$

Barriers

The transition to the 6-year programme in Japan has also had many challenges. Those challenges include insufficient numbers of academic staff in the clinical pharmacy area; lack of experienced preceptors; barriers to providing clinical pharmacy activities due to a high volume of prescriptions; and other health care professionals still having doubts about the role of pharmacists. ${ }^{30}$

\section{The PharmD curriculum}

The 6-year programme provides students with more pharmaceutical care, pharmacy practice, and pharmacotherapy courses. It includes 2.5 month rotations in hospital and community pharmacy settings, which are longer than the 4-year programme that included only 2-4 week hospital pharmacy rotation. ${ }^{30}$

\section{SOUTH KOREA}

\section{Need for the change}

The curriculum changes in the Republic of Korea (South Korea) was made to address the significant change in pharmacy practice, since a new prescription law was enacted in $2000 .^{15}$ The new law completely separates the prescribing and dispensing functions between physicians and pharmacists. These conditions were aimed to address certain public health issues; in particular, high rates of drug misuse and overuse. ${ }^{57}$ However, pharmacists' compliance with their new roles has been suboptimal. This result is because of the 4-year BPharm programme had mainly focused on the pharmaceutical sciences and most graduates had inadequate preparation to equip them to provide clinical services. ${ }^{15}$

\section{Process of the transition to the PharmD degree}

In order to cope with the scope of Korean pharmacy practice and align with the global trend toward 6-year pharmacy programmes, the Ministry of Education and 
Human Resources Development of Korea reorganised the pharmacy programme in $2005 . .^{15,20}$ The transition from the 4-year programme to the 6-year programme was fully implemented in 2009. ${ }^{20}$

\section{Enablers}

According to the new situation regarding prescription, Korean pharmacists are required to perform drug use evaluation and medication counselling for a patient prior to dispensing. $^{15}$

Barriers

There is the need to build infrastructure for the pharmacy practice experiences such as networking with training sites and preceptors. There is also a need to develop facilities and resources; in particular funds, manpower and knowledge. $^{58}$

\section{The PharmD curriculum}

The new curriculum includes a 2-year pre-pharmacy course and 4 years of pharmacy with practice experience. ${ }^{15,59}$

\section{PAKISTAN}

\section{Need for the change}

There were two main motivations for the transition to a PharmD programme in Pakistan. ${ }^{60}$ The first motivation was to provide a way for future graduates to practice in the U.S.; second was to develop the new curriculum to prepare the future pharmacist to have the capacity to work in various careers in Pakistan, especially in the patient care area. ${ }^{21,60,61}$

\section{Process of the transition to the PharmD degree}

In 2004, the Higher Education Commission (HEC) of Pakistan upgraded the 4-year BPharm to the 5-year PharmD programme in order to standardise the Pakistani pharmacy educational system, according to international education and practice needs. ${ }^{60,62}$ It had been announced that the 5-year PharmD was the essential condition for a university's PharmD accreditation, and a requirement for a pharmacist to practice in Pakistan. ${ }^{60}$

Enablers

The government hired a broad range of pharmacists in major public hospitals in order to establish and provide pharmaceutical services and to serve as training sites for the PharmD graduates in the future. ${ }^{21}$

Barriers

There were concerns about an inadequate number of experienced and qualified academic staff in the pharmacy practice area, lack of practice based-settings, as well as the insufficient clinical content and practice training in the PharmD programme, all of which may lead to low quality of education and low student satisfaction and performance. ${ }^{18,24,60,62,63}$ Secondly, there are many challenges for PharmD graduates in practice; for example, lack of an acceptance by other health professionals, the dispenser in pharmacies and hospitals performing the pharmacists' jobs; lack of the public awareness of the pharmacists' roles, and a severe pharmacy workforce shortage. $^{4,60,62,64,65}$

\section{The 5-year PharmD curriculum}

The 5-year PharmD programme had increased content and practice in pharmaceutical care and the clinical pharmacy clerkship. However, there were reports that the clinical and social aspects of pharmacy; in particular patient counselling, research methods and evidence-based medicines, as well as other major areas (e.g., public health pharmacy and drug policy) were not included in the new curriculum. ${ }^{10,60,66}$

\section{THAILAND}

\section{Need for the change}

Thai policy makers believed that a transition to the 6-year PharmD would meet the needs of the stakeholders by changing pharmacy competencies from generalists to specialists, resolve the issue of curriculum overload for the high-credit 5-year BPharm programme, and produce equal educational standards and outcomes and for the pharmacy profession on a national level. ${ }^{67}$

\section{Process of the transition to the PharmD degree}

Enablers

An important influence that has been mentioned on the transition to an all-PharmD programme in Thailand was the cooperation of four faculties of pharmacy and the Bureau of Health Service System Development, Ministry of Public Health (MoPH), in the development and establishment of a master's degree in clinical pharmacy via a modular system programme. This foundation of clinical pharmacy activities in real workplace settings was supported by the U.S.-Thai consortium for the development of pharmacy education in Thailand, which was founded in May 1994 by the Pharmacy Education Consortium of Thailand (PECT). Another big drive for advancement came from the announcement of the Pharmacy Council of Thailand (PCT) in 2008 that, starting in 2014, all new pharmacy graduates who are able to enter national pharmacy license examination would have to graduate from pharmacy faculties accredited by the Council through the 6-year PharmD curriculum only. ${ }^{67}$

Barriers

There were concerns about the higher costs of a longer period of time for study and an insufficient quantity and varying quality of PharmD preceptors and training sites. ${ }^{67}$

\section{The 6-year PharmD curriculum}

There are three tracks of PharmD in Thailand which are as follows; the pharmaceutical care PharmD which focused on patient care; the industrial pharmacy PharmD which is pharmaceutical product oriented, and the health consumer protection which focused on consumer protection mechanism regarding pre-marketing control, postmarketing control and consumer empowerment. ${ }^{68-70}$ 


\begin{tabular}{|c|c|c|c|c|c|}
\hline & $U S^{19,38,43,45,52}$ & $\operatorname{Japan}^{30,51,52,54}$ & South Korea ${ }^{15,20,58,74}$ & Pakistan $^{21,33,60-62}$ & Thailand $^{81,82}$ \\
\hline Need for the transition & $\begin{array}{l}\text { To have a highly skilled clinical } \\
\text { pharmacist to provide the } \\
\text { pharmaceutical care and work } \\
\text { with health care teams }\end{array}$ & $\begin{array}{l}\text { To cope with the regulations that } \\
\text { changes in the scope of } \\
\text { pharmacy practice in their } \\
\text { countries }\end{array}$ & $\begin{array}{l}\text { To cope with the regulations that } \\
\text { changes in the scope of pharmacy } \\
\text { practice }\end{array}$ & $\begin{array}{l}\text { To standardise the Pakistani } \\
\text { pharmacy educational system } \\
\text { and enable the graduates to } \\
\text { work abroad }\end{array}$ & $\begin{array}{l}\text { The 6-year PharmD will produce } \\
\text { pharmacy graduates who had } \\
\text { knowledge and skills needed by the } \\
\text { job market. }\end{array}$ \\
\hline Previous programme & 5-year Bachelor & 4-year BPharm & 4-year BPharm & 4-year BPharm & 5-year BPharm \\
\hline New programme & 6-year PharmD (PC $)$ & 6-year BPharm (PC $\left.{ }^{a}\right)$ & 6-year programme $\left(\mathrm{PC}^{\mathrm{a}}, \mathrm{IP}^{\mathrm{b}}\right)$ & 5-year PharmD $\left(\mathrm{PC}^{\mathrm{a}}, \mathrm{IP}^{\mathrm{b}}\right)$ & 6-year PharmD $\left(\mathrm{PC}^{\mathrm{a}}, \mathrm{IP}^{\mathrm{b}}, \mathrm{CP}^{\mathrm{c}}\right)$ \\
\hline $\begin{array}{l}\text { The difference } \\
\text { between the previous } \\
\text { and the } 6 \text {-year } \\
\text { curriculum }\end{array}$ & $\begin{array}{l}\text { PharmD curricula were extended } \\
\text { by one year that includes } \\
\text { additional patient care } \\
\text { coursework }\end{array}$ & $\begin{array}{l}\text { The new 6-year BPharm } \\
\text { programme focused on patient } \\
\text { care. }\end{array}$ & $\begin{array}{l}\text { The new programme increases the } \\
\text { number of required courses in } \\
\text { clinical pharmacy and training } \\
\text { period. }\end{array}$ & $\begin{array}{l}\text { Increase knowledge and } \\
\text { practice in pharmaceutical care } \\
\text { and the clinical pharmacy } \\
\text { clerkship }\end{array}$ & $\begin{array}{l}\text { The 6-year PharmD increased } \\
\text { practice hours. }\end{array}$ \\
\hline Process of transition & $\begin{array}{l}\text { In } 1997, \text { the ACPE decreed that } \\
\text { they would no longer accredit } \\
\text { BPharm programmes in } 2000 \\
\text { and all schools of pharmacy had } \\
\text { to convert to the PharmD as the } \\
\text { sole professional degree. }\end{array}$ & $\begin{array}{l}\text { Proposed by the } \mathrm{JPA}^{\mathrm{e}} \text { in } 1973 \text { and } \\
\text { approved by the Council for } \\
\text { Pharmaceutical Education in } \\
2003 \text {. }\end{array}$ & $\begin{array}{l}\text { The Ministry of Education and } \\
\text { Human Resources Development of } \\
\text { Korea reorganised the pharmacy } \\
\text { programme in 2005. The new } \\
\text { programme was fully implemented } \\
\text { in } 2009 \text {. }\end{array}$ & $\begin{array}{l}\text { In } 2004 \text {, the } \mathrm{HEC}^{f} \text { of Pakistan } \\
\text { upgraded the } 4 \text {-year BPharm to } \\
\text { the } 5 \text {-year PharmD programme } \\
\text { in } 2004 .\end{array}$ & $\begin{array}{l}\text { Proposed by the } \mathrm{PECT}^{\mathrm{g}} \text { and it was } \\
\text { mandated by the } \mathrm{PCT} \text { for pharmacy } \\
\text { licenses in } 2008 \text {. All schools moved } \\
\text { to the } 6 \text {-year programme in } 2010 \text {. }\end{array}$ \\
\hline Perceived barriers & $\begin{array}{l}\text { Difficulties to provide adequate } \\
\text { numbers of hospital-based } \\
\text { preceptors. }\end{array}$ & $\begin{array}{l}\text { Inadequate number of academic } \\
\text { staff in clinical pharmacy and } \\
\text { qualified preceptors. }\end{array}$ & $\begin{array}{l}\text { There is need to build } \\
\text { infrastructure for pharmacy } \\
\text { practice experiences. }\end{array}$ & $\begin{array}{l}\text { Limitations in pharmacy } \\
\text { education and limitation of } \\
\text { pharmacists' roles in clinical } \\
\text { settings }\end{array}$ & $\begin{array}{l}\text { Lack of long-term strategies for } \\
\text { reasonable implementation }\end{array}$ \\
\hline
\end{tabular}




\section{CONCLUSIONS}

Each country has different needs due to the different contexts of health care systems that are related to the scope of pharmacy practice. The countries should consider their needs critically before they decide to adopt the PharmD programme, in order to increase and ensure the benefits they will get from the new programme. Each country created a different process to handle the transition to an all-PharmD programme, but mostly had the process of school accreditation mandated by the appropriate regulatory bodies (Table 3). The barriers to the transition in most of countries are insufficient numbers of academic staff and preceptors in the clinical pharmacy area; insufficient experienced preceptors and training sites; barriers to providing clinical pharmacy activities in some countries due to a high volume of prescriptions and pharmacy workforce shortage. ${ }^{18,28,52,54,55,58,60,62,63,67}$ Finally, there still needs to be a framework or a set of indicators to measure and monitor the impact/outcome of the PharmD degree. This set of indicators should be used as a feedback loop to evaluate whether the transition balances the impacts/outcomes that meet the needs of the adopting country.

\section{CONFLICT OF INTEREST}

All authors declared no conflict of interest.

\section{FUNDING}

The authors gratefully acknowledge the financial support of the Thai Royal Government for the funds granted.

\section{References}

1. Pierce D, Peyton C. A historical cross-disciplinary perspective on the professional doctorate in occupational therapy. Am J Occup Ther. 1999;53(1):64-71. https://doi.org/10.5014/ajot.53.1.64

2. Francisco G. Doctor of Pharmacy, In: Dipiro J, ed. Encyclopedia of clinical pharmacy. New York: Marcel Dekker; 2003.

3. Babar Z, Scahill SL, Akhlaq M, Garg S. A bibliometric review of pharmacy education literature in the context of low-to middle-income countries. Currents Pharm Teach Learn.2013;5(3):218-232. https://doi.org/10.1016/i.cptl.2013.01.001

4. Anderson C, Futter B. PharmD or needs based education: which comes first? Am J Pharm Educ. 2009;73(5):92. https://doi.org/10.5688/aj730592

5. Alhamoudi A, Alnattah A. Pharmacy education in Saudi Arabia: The past, the present, and the future. Curr Pharm Teach Learn. 2018;10(1):54-60. https://doi.org/10.1016/i.cptl.2017.09.014

6. Bates I, Bruno A, Arakawa N. Global education description: 2013 FIPEd Global Education Report. 2013 FIPEd Global Education Report. http://www.fip.org/files/fip/FIPEd Global Education Report 2013 (accessed Mar 06, 2014).

7. Koleba T, Marin JG, Jewesson PJ. Entry-level PharmD degree programs in Canada: some facts and stakeholder opinions. Can Pharm J.2006;139(6):42-50. https://doi.org/10.1177\%2F171516350613900608

8. Opare A. All hail the first batch of PharmD graduates! https://psgh.org/news/409429/All-hail-the-first-batch-of-PharmDgraduates.htm (accessed Oct 23, 2018).

9. Ekpenyong A, Udoh A, Kpokiri E, Bates I. An analysis of pharmacy workforce capacity in Nigeria. J Pharm Policy Pract. 2018;11:20. https://doi.org/10.1186/s40545-018-0147-9

10. Hassain A, Jamshed S. Pharmacy practice in Pakistan In: Fathelrahman AI, Ibrahim MIM, Wertheimer Al, eds. Pharmacy practice in developing countries: achievements and challenges. London: Elsevier; 2016.

11. Wibulpolprasert S. Thailand Health Profile 2008-2010. Bangkok: Printing Press, The War Veterans Organization of Thailand; 2010

12. Marriott JL. Comparison of International pharmacy curricula. www.monash.edu/ data/assets/pdf file/0006/178404/marriott-01.pdf (accessed Apr 1, 2016).

13. Sripanidkulchai B. Current pharmacy education and comunity pharmacy services in Japan. Khon Kaen:Faculty of Pharmaceutical Sciences, Khon Kaen University; 2012.

14. Sripanidkulchai $B$. The globalization and standard of pharmacy education in Thailand. www.thaipharma.net/images/intro 1181485913/AGM 3.pdf (accessed Apr 27, 2016).

15. Kim E, Ghimire S. Career perspectives of future graduates of the newly implemented 6 -year pharmacy educational system in South Korea. Am J Pharm Educ. 2013;77(2):37. https://doi.org/10.5688/ajpe77237

16. General Pharmaceutical Council. Future pharmacists: standards for the initial education and training of pharmacists. http://www.pharmacyregulation.org/sites/default/files/GPhC Future Pharmacists.pdf (accessed April 4, 2016).

17. Murtaza G, Kousar R, Azhar S, Khan SA, Mahmood Q. What do the hospital pharmacists think about the quality of pharmaceutical care services in a Pakistani province? a mixed methodology study. Biomed Res Int. 2015;2015:756180. https://doi.org/10.1155/2015/756180

18. Jamshed S, Babar ZU, Masood I. The PharmD degree in developing countries. Am J Pharm Educ. 2007;71(6):125. https://doi.org/10.5688/aj7106125

19. Bright DR, Adams AJ, Black CD, Powers MF. The mandatory residency dilemma: parallels to historical transitions in pharmacy education. Ann Pharmacother. 2010;44(11):1793-1799. https://doi.org/10.1345/aph.1P394

20. Yoo S, Song S, Lee S, Kwon K, Kim E.Addressing the academic gap between 4- and 6-year pharmacy programs in South Korea. Am J Pharm Educ. 2014;78(8):149. https://doi.org/10.5688/ajpe788149

21. Hadi MA, Hughes J. Broader perspective needed on the PharmD degree in Pakistan. Am J Pharm Educ. 2009;73(6):114.

22. Ahmed SI, Hassali MA. The controversy of PharmD degree. Am J Pharm Educ. 2008 Jun 15;72(3):71. https://doi.org/10.5688/aj720371 
23. Khan T, Anwar M, Ahmed KM. A perspective for clinical pharmacy curriculum development and validation in Asian developing nations. J Young Pharm. 2011;3(2):151-154. https://doi.org/10.4103/0975-1483.80304

24. Amir M. The after effects of implementing the PharmD degree in developing countries. Am J Pharm Educ. 2011;75(6):124. https://doi.org/10.5688/ajpe756124

25. Frankel G, Louizos C, Austin Z. Canadian educational approaches for the advancement of pharmacy practice. Am J Pharm Educ. 2014;78(7):143. https://doi.org/10.5688/ajpe787143

26. Kishi DT. Japanese pharmaceutical education: implications for Americans teaching Japanese pharmacy students. Am $J$ Health Syst Pharm. 2001;58(11):1032-1035. https://doi.org/10.1093/aihp/58.11.1032

27. Knapp DA. The rocky road to educational change: adopting the entry-level PharmD at Maryland, 1989-93. J Am Pharm Assoc (2003). 2011;51(6):692-701. https://doi.org/10.1331/JAPhA.2011.10156

28. Akaho E, MacLaughlin EJ, Takeuchi Y. Comparison of prescription reimbursement methodologies in Japan and the United States. J Am Pharm Assoc (2003). 2003;43(4):519-526. https://doi.org/10.1331/154434503322226275

29. The Centers for Medicare \& Medicaid Services. What's Medicare? www.medicare.gov/sign-up-chage-plans/decide-howto-get-medicare/whats-medicare/what-is-medicare.html (accessed May 16, 2016).

30. Watanabe T, Ohtani Y, Yamamoto T, Nemoto Y, Ida Y, Bachynsky JA. The case for a shift in pharmacists' activities and pharmacy education: based on those in the English speaking Western countries. Yakuga Zasshi.2005;125(3):283-292.

31. Madiha M, Yang C. Curriculum and pharmacy practice experience offered for Pharm-D in Pakistan: needs and possiblities. Int Curr Pharm J.2014;3(8):313-317. https://doi.org/10.3329/icpj.v3i8.19406

32. Anderson C, Bates I, Brock T, Brown AN, Bruno A, Futter B, Rennie T, Rouse MJ. Needs-based education in the context of globalization. Am J Pharm Educ. 2012;76(4):56. https://doi.org/10.5688/ajpe76456

33. Hadi MA. PharmD and needs-based education: alternate view. Am J Pharm Educ 2010;74(7):125.

34. Hill DS. The "Entry-Level" Doctor of Pharmacy (Pharm.D.) Degree Issue for Schools of Pharmacy in Canada: Association of Faculties of Pharmacy of Canada: Background Paper; 1999.

35. Gans JA. Freedom of opportunity: the PharmD degree. Am Pharm.1990;30(6):24-7.

36. American Association of Colleges of Pharmacy. Commission to implement change in pharmaceutical education, background paper 3. www.aacp.org/resources/historicaldocuments/Documents/COMMISSPOSPAPER3.pdf (accessed Apr 4, 2016).

37. Elenbass RM, Worthen DB. Clinical pharmacy in the United States: Transformation of a profession. Lenexa: ACCP; 2009.

38. Carter BL. Evolution of clinical pharmacy in the USA and future directions for patient care. Drugs Aging. 2016;33(3):169177. https://doi.org/10.1007/s40266-016-0349-2

39. Boss MA, Lowther MA. Factors influencing curriculum change in professional programs. In: The Annual Meeting of the Association for the Study of Higher Education (ASHE). Pennsylvania. 1993.

40. Hepler CD, Strand LM. Opportunities and responsibilities in pharmaceutical care. Am J Health-Syst Pharm.1990;47(3):533-543.

41. Marcellus G. State university system of Florida: Pharmacy program review. 1995:State Univ. System of Florida, Tallahassee.

42. Barnett $\mathrm{C}$, Matthews $\mathrm{H}$. Practice patterns of BS, post-baccalaureate PharmD and entry-level PharmD graduates of one school of pharmacy. Am J Pharm Educ.1992;56(4):367-373

43. American Society of Health-System Pharmacists, Scheckelhoff DJ, Bush CG; American Association of Colleges of Pharmacy, Flynn AA, MacKinnon GE 3rd, Myers CE, Kahaleh AA, Knapp KK, Meier JL, Schwinghammer TL, Sheaffer SL, Thompson BJ, McCluskey CF 3rd. Capacity of hospitals to partner with academia to meet experiential education requirements for pharmacy students. Am J Health Syst Pharm. 2008 Nov 1;65(21):e53-e71. https://doi.org/10.2146/ajhp080150e

44. Lovett AW, Peasah SK, Xiao H, Ryan GJ, Perkins P. Introduction to pharmacy profession. Burlington, MA: Jones \& Bartlett Learning; 2014.

45. Kreling DH, Doucette WR, Chang EH, Gaither CA, Mott DA, Schommer JC. Practice characteristics of Bachelor of Science and Doctor of Pharmacy degreed pharmacists based on the 2009 national workforce survey. Am J Pharm Educ. 2010;74(9):159. https://doi.org/10.5688/aj7409159

46. Nemire RE, Meyer SM. Educating students for practice: Educational outcomes and community experience. Am J Pharm Educ. 2006;70(1):20. https://doi.org/10.5688/aj700120

47. Center for the Advancement of Pharmaceutical Education Advisory Panel on Education Outcomes. Educational Outcomes 2004. http://www.aacp.org/resources/education/Documents/CAPE2004.pdf (accessed Apr 5, 2016).

48. Accreditation Council for Pharmacy Education. Accreditation standards and key elements for the professional program in pharmacy leading to the Doctor of Pharmacy degree: Standard 2016. www.acpeaccredit.org/pdf/Standards2016FINAL.pdf (accessed April 5, 2016).

49. Islam MA, Khan SA, Sunaseelan S, Talukder R. Specialty education for student pharmacist and PharmD graduates in U.S. colleges and schools of pharmacy. Curr Pharm Teach Learn. 2016;8(2):184-190. https://doi.org/10.1016/j.cptl.2015.12.001

50. Engels MJ, Flint NB, Corbett SM, Mieure KD, Newkirk G, Phelps P, Price-Goodnow V, Williams J, Brummond PW. Overcoming the pharmacy residency capacity challenge as 2020 draws near. Curr Pharm Teach Learn.2015;7(3):405410. https://doi.org/10.1016/i.cptl.2014.12.011

51. Kurosawa N. Continuing pharmacy education in Japan. http://www.accp.com/international/index.aspx?iss=0511\&art=3 (accessed Apr 22, 2016).

52. Dolder C, Nakagawa S, Sakamaki A, Supernaw R. Changes in Japanese pharmacy education and practice. Am J Health Syst Pharm. 2008;65(3):201-202 
53. Kanke M. Pharmacy education in Asia and the Asian Assoc of Schools of Pharmacy. http://www.aacp.org/governance/SIGS/global/Documents/Pharmacy\%20Education\%20in\%20Asia.pdf (accessed Jul 12, 2014)

54. Inoue K. Accreditation of pharmacy education in Japan. Yakugaku Zasshi. 2007;127(6):953-972. https://doi.org/10.1248/yakushi.127.953

55. Inoue Y, Morita Y, Takikawa M, Takao K, Kanamoto I, Sugibayashi K.Future expectations for Japanese pharmacists as compared to the rest of the world. Res Social Adm Pharm. 2015;11(3):448-458. https://doi.org/10.1016/j.sapharm.2014.08.007

56. Watanabe T, Ohtani $Y$, Yamamoto T, Nemoto $Y$, Ida $Y$, Bachynsky JA.Pharmaceutical terms reflecting the change in practice in Japan. Yakugaku Zasshi. 2005;125(3):271-281. https://doi.org/10.1248/yakushi.125.271

57. Cho H-K. Challenges and opportunities posed by a new prescription law in South Korea. Am J Health Syst Pharm 2002;59(18):1780-1782. https://doi.org/10.1093/ajhp/59.18.1780

58. Choi SE. Development of new pharmacy degrees from the Korea University's perspective. www.archive.u21health.org/sites/u21health.org/files/Pharmacy\%20Education\%20in\%20KU 1.pdf (accessed Apr 25,2016).

59. Korean Pharmaceutical Association. 6-year program at colleges of pharmacy (2-year + 4-year system). www.eng.kpanet.or.kr/pharmacist/pharmacist04.jsp (accessed Apr 25, 2016).

60. Khan TM. Challenges to pharmacy and pharmacy practice in Pakistan. Australas Med J.2011;4(4):230-235. https://doi.org/10.4066\%2FAMJ.2011.488

61. The Pakistan Pharmacy Council. Aims \& objectives of the PharmD degree. www.pharmacycouncil.org.pk/doc/Pharm\%20D\%20Curriculum\%20Final\%202013.pdf (accessed Apr 4, 2016).

62. Madiha, Yang CQ. Curriculum and pharmacy practice experience offered for Pharm-D in Pakistan: needs and possiblities. Int Curr Pharm J. 2014;3(8):313-317.

63. Jamshed S. PharmD in Pakistan: a tag or a degree? Am J Pharm Educ 2009;73(1):13.

64. Ghayur MN. Pharmacy education in developing countries: need for a change. Am J Pharm Educ. 2008;72(4):94.

65. FIP (International Pharmaceutical Federation). Global pharmacy workforce intelligence: trends report. http://www.fip.org/educationreports (accessed Apr 25,2016).

66. Khan MU, Ahmad A, Hussain K, Salam A, Hasnain ZU, Patel I. The need for redesigned pharmacy practice courses in Pakistan: the perspectives of senior pharmacy students. J Educ Eval Health Prof. 2015;12:27. https://doi.org/10.3352/jeehp.2015.12.27

67. Chanakit T, Low BY, Wongpoowarak P, Moolasarn S, Anderson C. Does a transition in education equate to a transition in practice? Thai stakeholder's perceptions of the introduction of the Doctor of Pharmacy programme. BMC Med Educ. 2015;15:205. https://doi.org/10.1186/s12909-015-0473-4

68. Sumpradit N, Suttajit S, Hunnangkul S, Wisaijohn T, Putthasri W. Comparison of self-reported professional competency across pharmacy education programs: a survey of Thai pharmacy graduates enrolled in the public service program. Adv Med Educ Pract. 2014;5:347-357. https://doi.org/10.2147/AMEP.S67391

69. Suttajit S, Suwannaprom P, Supapaan T, Eakanunkul S, Tangkiatkumjai M, Kongkaew C, Anderson C, Wongpoowarak P Are we on the right track? Answers from a national survey of Thai graduates' perceptions during the transition to the 6year PharmD program. Adv Med Educ Pract. 2018;9:713-722. https://doi.org/10.2147/AMEP.S173014

70. Karnwareetip S, Surawichai A, Ruanta Y. Health consumer protection officers' perspective toward the problems and the mechanism of consumer protection involving health products in upper northern thailand. Mahidol Univ J Pharm Sci 2016;43(2):63-67.

71. WHO. United States of America: WHO statistical profile. www.who.int/gho/countries/usa.pdf?ua=1 (accessed Apr 28 2016).

72. Teeters J, Brueckl M, Burns A, Flynn A. Pharmacy residency training in the future: a stakeholder's roundtable discussion Am J Health Syst Pharm. 2005;62(17):1817-1820. https://doi.org/10.2146/ajhp050195

73. National Institution for Academic Degrees and University Evaluation. Overview: quality assurance system in Higher Education, Japan. http://www.niad.ac.jp/english/overview jp e ver2.pdf (accessed May 10, 2016).

74. Chun CB, Kim SY, Lee JY, et al. Republic of Korea: health system review. www.euro.who.int/ data/assets/pdf file/0019/101476/E93762.pdf (accessed Apr 27, 2016).

75. Ibrahim MIM, Fathelrahman AI, Wertheimer A I. Comparative analysis and conclusion. In: Fathelrahman AI, Ibrahim MIM, Wertheimer Al, eds. Pharmacy practice in developing countries: achievements and challenges. Elsevier: London; 2016.

76. Aslam N, Ahmed KZ. Clinical pharmacy clerkship in Pakistan: a leap from paper to practice. Inov Pharm. 2011;2(2):39.

77. Pharmacy Council of Pakistan. Recognition Status of Pharmacy Institutions. Accessed 28 Oct, 2018.

78. Prapunwattana M. Thailand pharmacy professional assembly (99 years), In: Nonthaburi. The Pharmacy Council of Thailand; 2012.

79. International Pharmaceutical Federation (FIP). FIP Global Pharmacy: Workforce report, Gal D, Editor. 2012, The Hague, FIP; 2012.

80. Sugibayashi K. Harmonization of Asia Pacific Pharmacy and Pharmaceutical Sciences Education, in 5th Asia Pacific Pharmacy Education Workshop. 2014, Faculty of Pharmaceutical Sciences Chulalongkorn University, Bangkok.

81. The Pharmacy Council of Thailand. The Pharmacy Council Announcement No 12/2008: Accreditation criteria for Faculty of Pharmacy and pharmacy curriculum. http://pharmacycouncil.org/share/file/file 258.pdf (accessed Jun 25, 2015)

82. Pongcharoensuk P, Prakongpan S. Centennial pharmacy education in Thailand. JAASP. 2012;1(1):8-15. 